\title{
IS INDIAN SMALL INDUSTRY POISED FOR INNOVATION?
}

\author{
Elangovan $\mathrm{R}^{1}{ }^{1}$, Thangavel $\mathrm{N}^{2}$ \\ ${ }^{1}$ Research Scholar, Sathyabama University, Jeppiaar Nagar, Rajiv Gandhi Road, Chennai, India \\ ${ }^{2}$ Jeppiaar Engineering College, Rajiv Gandhi Road, Chennai, India \\ E-mail : ${ }^{2}$ thangavelraj@gmail.com
}

\begin{abstract}
Indian Small Scale industry (SSI) gained popularity by accomplishing to a great extent the socio-economic objectives like employee generation, decentralization of industries, economic equality and exploitation of entrepreneurial talents. This sector played a crucial role of providing as many as 30 million jobs in the last 50 years. In the present scenario this industry accounts for about 95 percent of industrial units and about 80 percent of manufacturing employment (Gupta, 2001). This industry contributed a share of 40 percent in India's manufacturing production and a share of 35 percent in exports. Although the industry grew in numbers, they did not grow in size and scope. In spite of the favorable policy support by way of financial, fiscal and infra structural facilities extended to the small industry by the Governments for over last fifty years, it continues to be organizationally, financially and technologically weak. The liberalization and globalization policies of the major reform process in the year 1991 have exposed the small industry to fierce domestic and global competition. While declining credit flow and infrastructural inadequacies are common constraints faced by the small industry, use of obsolete technology and absence of innovative practices are likely to strangle the small industry in its long term survival and growth. This paper examines the suitability and viability of Indian SSI to upgrade themselves to modern technology and embrace innovative practices as existing in the developed nations.
\end{abstract}

Key words : Liberalization and Globalization, Indian SSI, Decentralization, Entrepreneurial Talents.

\section{INTRODUCTION}

The economic reforms initiated in India in the year 1991 have affected the business environment on four counts(Shuji Uchikwa, 2002). First with the abolition of Industrial licensing, Private sectors were able to build and expand their capacity without regulation. Production of consumer durable goods started to meet the pent-up demand. Second, import quantitative regulation was relaxed and combined with radical reduction of import tariffs, Indian manufacturers could therefore import capital and intermediate goods easily. Third the growth rate of public investment has decelerated. Private sector had the option to procure money from financial market in addition to banking. Fourth the removal of constraints for foreign investments helped Multinational companies set up their manufacturing business in India. These measures have impacted the Indian manufacturing sector very much and competition intensified. Both the large scale and small scale Industries were subject to domestic and global competition. Increasing customer preferences for variety and local industrial needs have changed the ground rules of competition from the mass production of standardized products to 'flexible specialization' of manufacturing customized products.

Few constraints expressed by SSI in operating their business are worthy of mention. Raw Materials are decontrolled but their prices shoots up. The zoom in prices is seen not in months but even in weeks. The markets have become overcrowded. Added to the woes, there is flooding of imported products. Lack of demand for small industry products is cited a prime reason for the sickness of small industry. Exports have become harder because of quality restrictions imposed by foreign buyers. Banks were given operational freedom. Viability is stressed but not their accountability. Most of the SSI are verified to suffer from cash crunch particularly of working capital inadequacies. Reservation policy of exclusive manufacture of more than 800 items by SSI was already thwarted by the Indian Government, thereby the small industries are no more insulated from competition. The number of sick SSI units reported in the III All India Census of small scale Industries (2001-2002) is $14.47 \%$. The SSI are forced to adopt the usual strategy of cost reduction, quality improvement, improving labour productivity, capacity utilization, etc. There is an implicit shift in the thrust of small industry policy from protection to competition. As a result, responding to technological changes and satisfying the expectations of customers have become indispensable for SSI firms to survive and grow. When necessity is stated to be mother of invention, competition has become mother of 'innovation'. The inevitability of embracing modern technology and innovative practices stems from either internal or external environment. Internal factors are personal motivation of the business owner and in house technological capacity. External factors refer to competitive pressure, technological changes, customer needs/uses, or 
information provided by the equipment suppliers and competitors.

The objective of this paper is two fold:

I. To project an overview of Indian SSI, Innovation and its aspects, role of SSI and impact of SSI on innovation.

ii. To examine the suitability and viability of SSI to embrace modern technology and adopt innovative practices in their business.

The paper is organized in four sections. Section II projects an overview of Indian SSI, innovation and its general aspects. In section III, a critical analysis is done with reference to the suitability and viability of SSI industry to update their technology and adhere to the innovative strategies in their business ventures. Section IV brings out a brief discussion with concluding remarks.

\section{ETHOS OF INDIAN SMALL INDUSTRY}

Indian business can be categorized into five segments: (i) Public sector units (PSU) of the Central State Governments. (ii) Multinational Companies (MNC). (iii) Business family managed enterprises. (iv) Non-Business family entrepreneur run business. (v) Micro, small and Medium enterprise(Phabsakkar, 2005). This class covers enterprises such as Proprietorship, association of persons, cooperative society, partnership firm, company or undertaking. The investment by way of plant and machinery for micro, small and medium enterprise is restricted to twenty five lakh, five crore and ten crore rupees respectively. In India, unlike the high income group countries, the definition of the small industry is not based on either business turnover or employees or both but on the investment cost in plant and machinery (GOI, 2006). Small industries were broadly classified into two sectors: Traditional small scale sector and Modern small scale sector. Traditional sector is artisan based and it consists of (i) Kadhi and Village Industries (ii) Handloom (iii) Handicrafts (iv) Coir and (v) Sericulture (Vasant Dasai, 2003). Modern small scale Industries use electrical power driven machinery and consist of (i) Small industries (ii) Ancillary units (iii) Export oriented units (iv) Micro enterprises (v) Small scale services and Business enterprises (SSSBE) and (vi) Women enterprises. Small firms are the ones which have only a small share of its market, are managed in a personalized way by their owners or part owners and which are not sufficiently large to have access to the capital market for the public issue or placing of securities. The small firms are characterized by (i) Ease of entry: No industrial license is required for starting the small industry. Registration of the firm with the Government also is not required. The numbers of registered and unregistered small firms in India are 1.87 million and 10.47 million units respectively. (ii) They rely on indigenous re-sources i.e.; locally available raw materials, local transports, indigenous machines and hire local laborers etc. More than 90 percent of small firms are family owned units. They do small scale operations in labour intensive industries with adapted technology with Skills acquired on the job and outside the job. They are subject to unregulated and competitive markets. Two typical characteristics of the small firms are their heterogeneity of its manufactured products and their business founders. About 7500 items are manufactured by SSI. The SSI units are fragmented throughout the length and breadth of the country. The SSI owners were drawn into the business from various groups and different situations. External events often force the entrepreneurs to take the major step of setting up a business of their own. Their typology and motivations are complex. For unemployed people, small firms are the last resorts to become self-employed. There are people who believe that small industry will take them from 'rags to riches'. The composition of the small industrialists is such that they form an assorted group of people who have their education ranging from $10^{\text {th }}$ standard up to the level of Ph.D. Being small and individually owned they are more flexible than larger firms. They are restricted by lack of resources, large firms by demand. Small firms because, they lack market power they cannot contribute to inflation. The maximum number of small firms are solo organizations with number of workers employed being very low and limited to a number 9 and below. The strength has been cautiously designed so that they cannot be brought under factory act. A group of 10 persons who use electric power comes under the purview of the factory act. Even with the nine workers the turnover is high and the labor is mobile. Most of the employees in the small unit may change their employees within a few years, sometimes even in a few months. The attrition rate is quite high in case of semiskilled and unskilled employees. A significant no of workers once they gain skills leave the firms for greener pasture. Go slow and strike may not be a worry, but high turn over and absenteeism are causes of concern. Their wages are 2 to 2.5 times lower than that of large firms. On the job training is not generally sought. SSI have very rough and ready methods of enterprise management and price fixing. The standards of technical management and book keeping are pretty poor. Their orientation is more operational than strategic and thumb rule based rather than professional (Padmanand, 2004). Manipulated financial statements are made in the small firms which may hide profitability to protect their margins with key customers, to bargain with labor force or to maximize tax out flows. Persons who, have setup small firms were initially lured to the business 
by the promise of fiscal incentives, subsidies and preferences in purchase. In spite of these limitations the SSI has emerged as a vibrant sector in the Indian economy in the last 50 years.

\section{Innovation}

Innovation is one word that is bandied about countless times in management literature and business conventions. U.S Dept of Commerce has defined Innovation as the combination of theoretical conception, technical invention and commercial exploitation. In its simplest definition, innovation is coming up with ideas and bringing them to life (Robert B.Tucker, 2002). Joesph Schumpter (1996) who was called the father of 'Innovation' described five types of Innovation.(i) Introduction of a new or improved good.(ii) Introduction of a new process(iii) Opening up of a new market.(iv) Identification of new sources of supply of raw materials, and (v) Creation of new types of Industrial organization. Peter Drucker (1985) elaborated this concept by saying that innovation is the specific tool of entrepreneurs, the means by which they exploit change as an opportunity for a different business or a different service. It is capable of being presented as a discipline capable of being learned and practiced. Bolton and Thompson (2000) associated invention with creativity but linked with entrepreneurship. Creativity was stated to be the starting point whether it is associated with invention or opportunity spotting. This creativity is turned to practical utility through innovation. Entrepreneurship then sets that innovation in the context of an enterprise which is something of recognized value. To them creativity and innovation need the entrepreneurial context to become a business reality. A simple model emerging the above stated definitions is as below:-

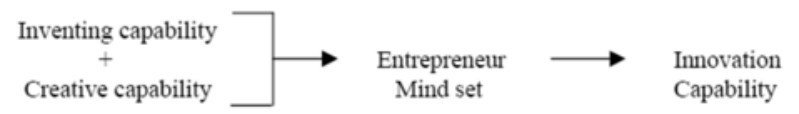

The three types of innovation generally known are i. product innovation ii. Process innovation iii. Strategic innovation. All tangibles, in tangibles, physical goods, or raw materials and services are covered under product innovation. Process innovation include such things as integrating new manufacturing methods and technologies that leads to cost, quality, cycle time, delivery time and development time of products. Strategy innovation results in new approach to marketing, new markets, new distribution channels, new value added services, etc. All the above stated innovations can be categorized further into three basic degrees: incremental, substantial and breakthrough innovations. Incremental innovations are small or minor changes which can affect even insignificant degree of financial impact but these innovations can be quickly matched by competitors. Substantial innovations are mid level in significance both to the customer's benefit and to the growth of the sponsoring company. Breakthrough innovations give rise to new products, services that yield a significant increase in revenue and profits. The characteristics of innovation are depicted in Table I (Vijay Govindarajan, 2005).

Table-1. Characteristics of Four different types of Innovation

\begin{tabular}{|l|c|c|c|}
\hline \multicolumn{1}{|c|}{ Innovation type } & $\begin{array}{c}\text { Expense of single } \\
\text { experiment }\end{array}$ & $\begin{array}{c}\text { Length of each } \\
\text { experiment }\end{array}$ & Ambiguity of results \\
\hline $\begin{array}{l}\text { Continuous process } \\
\text { improvement }\end{array}$ & Smallest & $\begin{array}{c}\text { Shortest } \\
\text { (could be days) }\end{array}$ \\
$\begin{array}{l}\text { Process revolution } \\
\text { Product service } \\
\text { innovation } \\
\text { Strategic innovation }\end{array}$ & $\begin{array}{c}\text { Largest } \\
\text { Larest }\end{array}$ & $\begin{array}{c}\text { Longest } \\
\text { (could be years) }\end{array}$ & Most ambiguous \\
\hline
\end{tabular}

From the point of view of business Managers any new product, process, service and technology is viewed as an innovation. However, the basic qualification for true Innovation must meet three basic criteria in tandem; (a) It must engage a creative process: This component refers to how a product, service, technology or process is created. The creative process involves finding a new solution to a problem which may require setting up (R\&D) and putting funds into it (b) It must be distinctive: This refers to the nature of discrete output arising out of the creative process. The granting of patent is a good measure of the distinctiveness. (c) It must yield a measurable impact: The third trait of innovation is impact or the realization of value from a new product, service, technology or process. Impact is the element that differentiates innovations from the mere inventions. One measure to evaluate the impact is to assess the power of patents - the number of times a patent is referenced by other patents. Innovations shall be evaluated according to these criteria based on both qualitative and quantitative information.

\section{ROLE OF SSI \& ITS IMPACT ON INNOVATION}

The Indian SSI operate in three ways (Thanulingom, 1985):- (i) Those in which small scale industry has to meet the competition of the corresponding large scale industry (eg:- Distribution, power transformers, etc). (ii) Those in which small scale industry is concerned with the manufacture of certain stages of production in a manufacturing process in which the predominant role is that of the large scale industry (eg: Auto mobile components). (iii) Those in which small scale production has certain advantages and is not affected by large scale industry to any greater extent.(eg:- items intended by electrical substations, defense, and space research organizations). Following this classification in SSI business a risk-profit matrix is drawn as below. This matrix is based on the experiences of SSI industrialists who have 
been in business for more than $15-20$ years.

Table 2 : Risk - Profit Matrix

\begin{tabular}{|c|l|c|c|}
\hline S.No & \multicolumn{1}{|c|}{ Dimension } & Risk & Profit \\
\hline 1 & $\begin{array}{l}\text { Products manufactured and supplied to markets/ } \\
\text { distributors. }\end{array}$ & $\begin{array}{c}\text { Low to } \\
\text { High }\end{array}$ & Low to High \\
\hline 2 (a) & $\begin{array}{l}\text { Components or sub-assemblies that got to be } \\
\text { fitted with main products manufacturer (OEM) }\end{array}$ & Moderate & Medium \\
\hline 2 (b) & $\begin{array}{l}\text { Outsourcing activities (sub- contracting/Labor } \\
\text { jobs) }\end{array}$ & Low & Low to medium \\
\hline 3 & Low volume or special (Niche) products & Low & Low to High \\
\hline
\end{tabular}

Survival of the third group of industries is quite independent of large scale units. This sector is engaged in specialty goods, import substitutes etc for which the both market demands and risks are low. However, they need technology and special innovative skills. The second group refers to out sourcing activities including labor jobs. Survival and growth of firms depend on its relationship management (RM) with large scale units. This sector is at the mercy of OEM (Original equipment Manufacturers) who supply guides, design drawings of the jobs to SSI who are required to replicate/ reproduce their original components. Sub contracting is typically associated with standard products based on mature and generally available technologies. The ancillary units who undertake labour jobs, are generally unhappy with large firms who are bent on fixing mercilessly Uneconomic prices on components produced by small units. Some process Innovations / improvements would be required to make their jobs cost effective. In the normal circumstances their business fetches constant or low returns. The first groups of firms depend on their ability to meet the challenges of the market forces. Or else they shall ensure some kind of protection to insulate themselves from competition of large firms. This is the sector which tries to thrive on updated technology \& fast innovation practices. Sometimes their risks and profits are not positively correlated. SSI are of various types and sizes. These are of 18 industries as per Indian specification. The SSI has been manufacturing 7500 items. Except basic goods, they manufacture capital, intermediate, and consumer (durable \&non- durable) goods like 1). Food, 2)Beverages, Tobacco 3)Cotton textiles 4)Wool, silk, synthetic, fiber 5)Jute, Hemp 6)Hosiery and readymade garments 7)Wood 8)Paper 9)Leather 10)Rubber and plastic 11)Chemical 12)Nonmetallic mineral 13)Basic metal 14)Metal products 15)Machinery parts 16)Electrical machinery 17)Transport equipments 18)Other manufacturing industries. The inevitability of introducing modern technology and innovation in the small business need not be over stated. The competitiveness of the industry depends on its ability to obtain inputs at competitive terms, effective value through efficient process and successfully marketing its output to downstream companies. This concept is depicted in the following figure

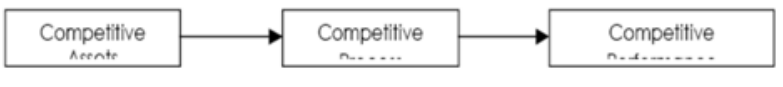

Fig .1 Competitiveness Model

The nature of (R\&D) /Innovative activities carried out by SSI are collected from the responses of 60 small industrialists who have been in business for more than two decades. The positive responses in percentage are recorded in Table.

Table - 3 : Natural of Technical/R\&D activities

\begin{tabular}{|c|l|c|}
\hline S.No & \multicolumn{1}{|c|}{ Dimensions } & Responses \\
\hline 1 & Existence of design and R\&D department & $\mathbf{1 0}$ \\
\hline 2 & Executing Incremental Innovative jobs & $\mathbf{7 5}$ \\
\hline 3 & $\begin{array}{l}\text { Exchange and up-dating of technical information } \\
\text { between customer and supplier. }\end{array}$ & $\mathbf{1 0 0}$ \\
\hline 4 & Laboratory and testing equipment availability & $\mathbf{3 6 . 6}$ \\
\hline 5 & Tool room facility availability & $\mathbf{3 6 . 6}$ \\
\hline 6 & Quality control plans adopted (iso 9000/9001/14000) & - \\
\hline 7 & Ability to understand and correct rejections & $\mathbf{1 0 0}$ \\
\hline 8 & Standardization, drawing files, etc. & 93.3 \\
\hline 9 & $\begin{array}{l}\text { Capability of changing product performance/ quality } \\
\text { by technical efforts }\end{array}$ & $\mathbf{1 0 0}$ \\
\hline 10 & Solving commonly encountered problems & $\mathbf{1 0 0}$ \\
\hline 11 & $\begin{array}{l}\text { Changing product shape/dimension to suite customer/ } \\
\text { market requirements }\end{array}$ & $\mathbf{1 0 0}$ \\
\hline 12 & Desire to develop new products & $\mathbf{7 3 . 3}$ \\
\hline 13 & Desire to use alternate/new materials & $\mathbf{7 6 . 7}$ \\
\hline 14 & Desire to develop new processes & $\mathbf{5 6 . 6}$ \\
\hline 15 & Modifying existing machinery/equipment & $\mathbf{5 0}$ \\
\hline 16 & Interest to introduce new technology & $\mathbf{9 0}$ \\
\hline
\end{tabular}

There are few inferences that could be got from the surveyed units : (i) About $60 \%$ of the units irrespective of their plant and machinery value and turn over were not enthusiastic about setting up adequately equipped laboratories or tool rooms. Only chemical, rubber and electronics SSI show some interest. (ii) SSI units donot carry out (R\&D) jobs as a matter of routine. Only when some specific problems are posed to them, they apply their minds to find practical solutions. Otherwise they are more inclined to execute routine jobs. (iii) About $50 \%$ of the SSI owners have a tendency to be conversant with their machines and processes. (iv) In spite of their interest for launching new products and processes, they have neither money nor time to undertake such exercises. (v) In $46 \%$ of the units the process of manufacturing is manual, $38 \%$ semi automatic and only $16 \%$ automatic. Modernization of machines moves at a snail's pace.

R\&D in Indian Industry:- India's (R\&D) expenditure though showing somewhat increase over a period of time but as a percent of national Income it is much less than in the developed world. The percentage figures are : India (0.86), USA (2.70), U.K (2.70), France (2.40) and Japan (2.70) India's Industrial (R\&D) expenditure as a share of total (R\&D) varies between $22 \%$ in $1985-86$ to $28 \%$ in 1996-97. Small enterprises are often stated to be more innovative than large ones because of their flexibility and willingness to adopt any new approach. The small firms 
are at advantage of absence of organizational barriers, establishment of informal contacts with environments, the managing team and employees personal concern in the firms prospects. Empirical studies have brought that small industries, in the developed world, in general, carry out things informally. This is true in Indian context also. But there is no available statistics to indicate the (R\&D) intensity of small industry in India. The positive relationship between (R\&D) and the size of the firm was substantiated by the study of Goldor and Reuganathar (1999). There is hardly any literature which have gone into the relationship between R\&D and the firm size in developing countries ( Balasubramanya, 2002).

Innovation Impact through Patents:- One way of measuring innovation is through its impact i.e. number of international patents that a country has accumulated. America's reputation for being a hot bed of innovation is well known. Developing countries like India have to go a long way in catching up with the other developed countries. The figures of Patents filed/patents issued are : India 1,278/405, China - 2,043/583, Japan $65,025 / 34,079$, U.K - 7,275/3,745 \& USA $2,25,000 / 95,000$.

The SSI is a highly non-homogenous sector in terms of product range, size. Value addition, capacity utilization, employment etc. There are significant inter industry and size-wise variations. It is only the SSI industries that are in the high end of the spectrum who can conceive (R\&D)/ Innovative jobs. While some of the dimensions of the SSI industry can be easily assessed from the available figures by different ratings like capital intensity, labor productivity, capital productivity, the (R\&D) intensity cannot be evaluated since no such figures are available. Though SSI incorporate few successful improvements in design/modification they do so without knowing that they carry out some incremental innovations.

Low risk appetite for intangibles: - Specifically Indians lack the appetite to invest in tangibles owing to an inherent disregard of their material value. Indian keeps supplying raw materials and other factors of production to the world rather than finished products (Abhishek Breja, 2005).

Lack of data and external communication: A great deal of information on consumer demographics, industry players, markets, new technical development, sources of technical assistance, Govt promotional measures etc are required by SSls who are at a disadvantage in not obtaining complete and consistent information and analysis of such information.

Lack of risk capital: Innovation is perceived to be both costly and risky. In India financial situations, commercial capital. Smaller firms experience difficulty in raising venture capital funds for high risk projects and particularly raising longer term capital. The lending by banks is based more on the quality of the applicant rather than the quality of the business idea. Statistics reveal that the proportion of advances to the small scale sector to the net advance, there has been a uniform decrease of $1 \%$ each year. The figures for the years 1997, $2001 \& 2005$ are 18.95, 11.99 and 7.68 percent.

Ownership structure: - During the early stages of evolution of the SSI sector to sustain the performance and for the growth of SSI businessmen, a reconstitution of the management from being a mere sole proprietorship to partnership was conceived. But as seen over a period of 20 years from the following table SSI units are increasingly run by proprietary concerns. The percentage of partnership in business has declined from 35\% I census(1972-73) to 6.36 III census(2001-02) whereas the properitorship increased from 61 percent (1972-73) to 90.09 percent (2001-02).

Change in SSI character: - From the latest III census data, the per unit factory employment in small firms has come down from 6.29 persons to 4.6. This could be the effect of modernization of machines of technological up gradation being resorted to the SSIs in the face of changed economic conditions. There is consequential increase in the per unit fixed investment is from Rs.1.6 Lakhs to Rs.7.11 Lakhs.

Table - 4: SSI-Census Indicators

\begin{tabular}{|c|c|c|c|}
\hline S.No & Indicator & $\begin{array}{c}\text { II census } \\
(1987-88)\end{array}$ & $\begin{array}{c}\text { III census } \\
\text { (2001-02) }\end{array}$ \\
\hline 1 & Per unit employment & 6.29 & 4.60 \\
\hline 2 & $\begin{array}{c}\text { Per unit fixed investment (Rs } \\
\text { Lakhs) }\end{array}$ & 1.60 & 7.11 \\
\hline
\end{tabular}

The ownership structure and the work force indicate that SSI are becoming lean and mean. The SSI's main handicap is its small size. It's bargaining power is also small.

Refusal to grow:- Small firms are preoccupied with day today affairs of coordinating their business activities. They are anxious about short term gains than long term planning and objectives. There are a variety of reasons for sacrificing their profit that growth of the firms could bring. All these stem from their psychological reasons. The most usual reasons expressed by them is that more business would just mean more worries and that they don't want. They look for steady business, a stable circle of clients and or regular contracts with large firms.Empirical evidences highlight a widespread reluctance among small business to grow (Golby 1971, Boswel 1972 and Gray 1992). They 
Some studies also found that majority of owner managers do not have the capacity or desire to grow their venture (Storey, 1994).

\section{DISCUSSION AND CONCLUSION}

A basic fact remains to be pointed out. While the tiny (Micro) Industries struggle for their existence; Small Industrialists strive to make a moderate living out of their small business. Medium class industrialists on the other hand are wealth creators. However, people of the three different tiers are mixed together to be called as micro, small and medium industries. This appears to be an unholy combination. There is no rapport, close relationship or communication maintained between small and medium business people for exchange of technical information and collaboration of innovative activities. However, the cooperation and understanding between small and micro industries is remarkable in solving technical and other issues. Most of the second generation or third generation SSI entrepreneurs are interested to modernize their machines and equipments and technology. But they have neither assured bank loan nor assured market. As on date, a firm with 10 persons with power comes under the purview of factories Act. This can be amended as 50 persons in the case of units with power and 100 persons in the cast of units without power. This effect of amendment in labour laws will not only bring in more employment opportunity but meaning ful claims of small firms for their expansion, diversification and (R\&D) activities. In the economic development of India over the last few decades, the most striking feature of the structural change in Indian economy had been the pre-eminence of service sector as the major contributor raising its share sharply in the national output (Papola, 2006). Industry particularly manufacturing which has been observed historically to be the main contributor of growth atleast in the initial years of economic development has stagnated since 199091(Table - 5). The average annual turn over is reported to be Rs 15.23 Lakh(Third Census, 2003).

Table-5. Pattern of Structural Changes

\begin{tabular}{|c|c|c|c|}
\hline Year & Agriculture (\%) & Industry (\%) & Services \\
\hline 1950 & 60 & 12 & 27 \\
\hline 2007 & 19 & 26 & 55 \\
\hline
\end{tabular}

Compared to other nations, the average annual industrial growth is not laudable. India remains a global office, while China has become a global factory by its manufacturing competence. The small firm owner is all in 'one' in his company. He assumes the roles of Human Resource Manager, Accounts Manager, Marketing Manager. Above all he is supposed to be a (R\&D) Manager also if at all he carries out a bit of improvement as and when occasions demand. Peter Drucker believes that one need to be of a certain size is to take advantage of opportunities and have enough depth of talents to be a really knowledge - based organization. He believes that this is a world of mediumsized. The true small business is probably at a disadvantage because it cannot know enough. The medium sized business - may be the business best positioned because it knows its markets, it knows its customers and yet it is big enough to do whatever is needed technically in terms of training people, of paying people in terms of investing for few years in an experiment. South Indian based medium industries like Cavin Care (shampoo), Suguna Chicken and Arun Ice creams whose annual turn over is above Rs 500 crores embarked on successful innovations which ultimately rewarded them well. The Indian definition of small industries is itself flawed. The definition of micro \& small \& medium industries is based on investment criteria (machines and machinery) whereas in the other developing countries these industries are defined in terms of sales turn over or employees strength or both. The man power in Indian small industries is axed by such definitions and unfavorable labour laws making the industry's structure weak and mean. Innovative activities have become their lowest priority in the agenda of their activities. 'Small is beautiful' according to Samuchar. For companies small is not beautiful (Mike Johnson, 1995). By having weak structure and poor resources, small industry cannot bring out any successful innovation. What they have been doing all along are small - incremental improvements or small incremental innovations. They will continue to do so. They fix a certain limit beyond which they cannot go. Summing up, it can be stated that Indian Small Industry is not in a position to be geared up to take on challenges of innovation in the current situation.

\section{REFERENCES}

[1] Abhishek Breja and Mohan Kurien Mathew, 2005, A Journal of Management Research Volume 4, Number 2, 2005: PP-129-130

[2] Balasubrahmanya M.H, 2002, R\&D and Firm size in the Small Industry sector in India, Sri Lankan Journal Management Vol 7 July-Dec 2002

[3] Development Commissioner (Small Scale Industries) 2003, Third All India census of Small Scale Industries 2001-2002, Appendix III, PP 35-36

[4] Government of India, 2006, 'The Gazette of India, Ministry of law and Justice, No 27 of $2006 \mathrm{dt} 16^{\text {th }}$ June, 2006, PP 5

[5] Gupta S.P, 2001, Report of the Study group on development of small scale enterprises, edited by Planning commission, Govt of India, PP1 
[6] Mike Johnson, 1995, Managing in the Mext Millennium, Butterworth Heinmann Letf, 1995 : PP 20-23

[7] Padmanand.V, 2004, Managing India's small Industrial economy, Response books 2004, PP 2-13

[8] Papola T.S. 2006, 'Emerging Structure of Indian Economy, Indian Economic Journal 54(1), PP:34-35.

[9] Phabsakkar S.J (2005), opportunity and strategies in Indian Business, New Delhi, PP 53-54

[10] Richard Scase and Robert Goffe, 1987, The Real World of the Small Business owner, Biddles Ltd, Great Britan, 1987, PP 22-23

[11] Robert B.Tucker, 2002, Driving Growth through Innovation, East West Books (Madras) Pvt Ltd, 2002 :PP 18-19

[12] Shuji Uchikawa, 2002, Economic Reforms and Industrial Structure in India, Manohar publishers, New Delhi, PP 29-30
[13] Thanulingom.N, 1985, Small Scale Industry Interrelationship with Large Scale Industry, Rainbow printers 1985, PP 3-4

[14] Vasant Desai, 2003, Management of Small Industry, Himalaya Publishing House, 2003, PP 6-9

[15] Vijay Govindarajan, 2005, 10 Rules for Strategic Innovation, Harvard Business School press, PP _ xxii

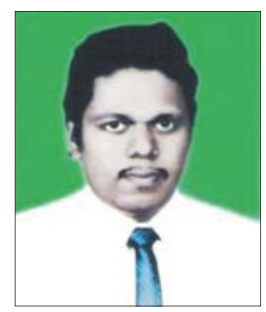

Mr. Elangovan has more than 30 years of industrial experience. $\mathrm{He}$ is a full time research scholar whose academic interests include Consumer-behaviour and Global Strategic Management. He has presented about 25 research papers in various conferences and published 3 papers in international journals. 